\title{
THE EFFECT OF MARKET ORIENTATION ON FINANCIAL VS. NON-FINANCIAL INDICATORS OF BUSINESS PERFORMANCE - COMPARISON OF MARKOR AND MKTOR APPROACH
}

\author{
Simona Budinska ${ }^{229}$ \\ Janka Taborecka-Petrovicova ${ }^{230}$ \\ https://doi.org/10.31410/itema.2018.572
}

\begin{abstract}
The paper deals with the issue of relationship between market orientation and business performance. Market orientation is considered as an established concept of marketing theory whose implementation within the business is regarded as the key to achieving competitive advantage and prosperity. The claim that market orientation has a positive impact on business performance is well documented in scholarly research. Although a few studies report a negative or non-significant relationship, predominant evidence shows a positive relationship between market orientation and business performance. Both concepts occupy the interest of scientists for decades and there exist studies worldwide presenting and confirming their dependences. Since in Slovakia there was research gap in this field we decided to examine this issue on the representative sample of 230 companies operating in Slovakia with various sizes (small, middle-sized, large) from different industries and regions. We applied established MKTOR and MARKOR methodology. The main aim was to examine relationship between market orientation measured via two different methods (MARKOR vs. MKTOR) and business performance measured through financial and non-financial indicators and to compare their results. In our hypothesis we assumed that market orientation has higher impact on nonfinancial indicators than on financial indicators of business performance in case of both methods. Our results confirmed this assumption and we found out that there is middle-strong positive correlation in the linkage to non-financial indicators and slightly lower correlation in the linkage to financial indicators. These findings may be used for managerial implications and successful implementation of marketing management concept into the practice of the businesses.
\end{abstract}

Keywords: market orientation, business performance, MARKOR, MKTOR, financial and nonfinancial indicators

\section{INTRODUCTION}

$\mathrm{D}$ espite the presence of market orientation concept in marketing literature for decades there is still unclear understanding of basis of market-oriented business. Also, Narver and Slater (1998) in their research notes wrote about inconsistency of market orientation elaboration in different fields. The essence of being market-oriented is well documented in marketing literature, however in management literature still continue debates about what does it mean to be market-oriented. They propose that this problem has occurred because scholars are talking about two separate management philosophies. They differ between the first, being "customer-led", short-term philosophy in which businesses respond to customers expressed needs and the second, being "market-oriented", long-term philosophy of

\footnotetext{
${ }^{229}$ Matej Bel University, Tajovskeho 10, 97590, Banska Bystrica, Slovakia

${ }^{230}$ Matej Bel University, Tajovskeho 10, 97590, Banska Bystrica, Slovakia
} 
commitment to understanding customers expressed and latent needs, and to producing superior customer value through the developing innovative solutions. Market-oriented businesses are committed to understand not only their customers, but also the capabilities and plans of their competitors. In order to understand both customers and competitors, market-oriented businesses systematically acquire and evaluate market information. Market-oriented businesses use the same traditional techniques of market research as customer-led businesses, but they combine these with the other to discover customers' latent needs and to drive generative learning. These businesses search for unserved markets representing potential customers, which are together with new products catalysts for organizational renewal in the market-oriented business.

Measurement of business performance through the financial indicators represents the most common way how to determine whether business achieves its objectives. Even if the financial indicators have several shortcomings, such as conditionality of data reliability from financial statements, they are indispensable when managers assess the business performance. Their advantages mainly consist in simplicity of getting data which are publicly available and their versatility what bring an opportunity to compare indicators within the business and also among businesses to each other. Financial indicators can be calculated from the available documents, such as financial statements or annual reports (Marinič, 2008). Lesáková (2004) states that businesses operating in Slovakia analyze predominantly profit as an evaluation criterion. Exceptionally, profitability indicators ROE and ROS are used. Other option is to focus on the achievement of several objectives, which may be equal or may be arranged in a hierarchical system. However, in the business there are issues that cannot be expressed through the financial indicators but affect the final results. Non-financial indicators will often appear to be more appropriate for defining the strategy and objectives of the business than financial ratios. Dubovická and Varcholová (2011) argue that to reach target financial ratios it is needed to achieve the value of non-financial indicators while both types of indicators are important aspects of business performance and lead to its long-term success. Financial and non-financial indicators relate to each other and in terms of strategic management complete the picture of the future situation in the business and bring the options to solve it.

\section{METHODOLOGY}

The main aim of our paper was to examine relationship between market orientation measured via two different methods (MARKOR vs. MKTOR) and business performance measured through financial and non-financial indicators and compare their results. In our hypothesis we assumed that market orientation has higher impact on non-financial indicators than on financial indicators of business performance in case of both methods. ${ }^{231}$ Firstly, we investigated market orientation among companies; secondly we studied their business performance measured through financial and non-financial indicators; thirdly we studied relationship between market orientation and particular financial and non-financial indicators; and finally we compared results based on these two different methods. Since in Slovakia there was a research gap in this field we decided to examine this issue on the representative sample of 230 companies operating in Slovakia with various sizes (small, middle-sized, large) from different industries and regions. To study market orientation we applied established MKTOR and MARKOR methodology. MKTOR represents cultural approach towards market orientation measurement and was developed by Narver and Slater in 1990. It consists of 20 statements divided into three groups

\footnotetext{
${ }^{231}$ The topic is part of the research project VEGA 1/0686/16 Marketing orientation of businesses as a tool of increasing business competitiveness and performance, 2016-2018, project coordinator: Janka TaboreckaPetrovicova, doc. Ing. PhD.
} 
- intelligence generation, intelligence dissemination, and responsiveness. The other common approach was behavioral one, where MARKOR method is used (Kohli, Jaworski, 1990), consisting of 14 items divided into three groups - customer orientation, competitor orientation, and inter-functional coordination.

It is obvious that conceptualizations, Kohli and Jaworski's behavioral perspective and Narver and Slater's cultural perspective, are characterized by different components and offer to researchers various ways how to examine market orientation. Despite of this there are significant overlaps between these conceptualizations. Cadogan and Diamantopoulos (1995) compared these conceptualizations and analyzed overlaps on a conceptual and operational basis. Conceptual overlaps consist in common features in market orientation definitions and operational overlaps are represented by similarities in measuring instruments. These scholars studied both conceptualizations in detail and compared each component to detect common features.

Based on the work of Kohli and Jaworski (1990, pp. 257-269), we decided to measure the performance of businesses through four groups of indicators which are impacted by market orientation. Three indicators represent non-financial performance: the organizational commitment of employees, "esprit de corps" and customer satisfaction. The other group of statements focuses on the performance using financial ratios. We selected indicators based on the work of many authors (Narver, Slater, 1990; Kohli, Jaworski, 1993 Avlonitis, Gounaris, 1997, Matsuno et al., 2002; Cervera et al., 2001; Puledran et al., 2003; Rojas -Méndez, Rod, 2012) and we selected those that were most frequently used in their researches and we tried to incorporate those indicators that Slovak businesses monitor and measure (Lesáková, 2004). In comparison with original studies, we decided to involve additionally some modern indicators, such as economic and market financial ratios (Kabát et al, 2013), and those that combine financial and non-financial indicators, especially Balanced Scorecard.

We decided to examine the growth of individual indicators during last three years. Our decision is supported by results of structuralized interviews when respondents expressed their opinion that businesses could have problems with fulfilling the questions about business performance requiring concrete numbers. Thus, we decided to examine business performance through subjective measures based on Likert-scales items which have positive or negative character. Negative formulation is used as a control tool for sustaining attention of respondent. We used only 7-point Likert-scale items because of the better comparability and interpretation. Here we followed the studies of several authors who used this approach (Narver, Slater, 1990; Pitt et al., 1996; Puledran a kol., 2003; Hooley et al., 2003).

\section{RESULTS}

In our hypothesis we assumed that market orientation has higher impact on non-financial indicators than on financial indicators of business performance. We realized correlation analysis to identify the impact of market orientation on various indicators. The p-value lower than significance level 0.01 or 0.05 means that there is significant correlation between market orientation and business performance indicators. Outputs from statistical program are shown in table 1 and table 2. Statistical testing confirmed significant correlation between market orientation measured through various methods and all tested non-financial indicators. Spearman's rho speaks about the middle-strong positive correlation in the linkage to employees commitment (MARKOR: +0.476 , MKTOR: +0.488 ), esprit de corps (MARKOR: +0.418 , MKTOR: +0.450 ), and customer satisfaction (MARKOR: +0.369 , MKTOR: +0.388 ). 
Relationship between market orientation measured through MKTOR method and all nonfinancial indicators was stronger than in case of MARKOR method.

Table 1: The Effect of Market Orientation on Non-financial Performance Indicators

\begin{tabular}{|l|c|c|c|c|}
\hline \multirow{2}{*}{} & \multicolumn{2}{|c|}{ MARKOR } & \multicolumn{2}{c|}{ MKTOR } \\
\cline { 2 - 5 } & p-value & $\begin{array}{c}\text { Spearman's } \\
\text { rho }\end{array}$ & p-value & $\begin{array}{c}\text { Spearman's } \\
\text { rho }\end{array}$ \\
\hline Employees Commitment & 0.000 & 0.476 & 0.000 & 0.488 \\
\hline Esprit de Corps & 0.000 & 0.418 & 0.000 & 0.450 \\
\hline Customer Satisfaction & 0.000 & 0.369 & 0.000 & 0.388 \\
\hline
\end{tabular}

The results of correlation analysis between market orientation and financial business performance indicators are shown in table 2. As we can see, there is statistically significant positive dependence between market orientation and all financial indicators. But we can also see that in prevailing cases stronger relationship between market orientation and business performance was in case of MARKOR method (exception represent ROA, ROI, ROE and ROMI).

Table 2: The Effect of Market Orientation on Financial Performance Indicators

\begin{tabular}{|l|c|c|c|c|}
\hline \multirow{2}{*}{ Overall Performance } & \multicolumn{2}{|c|}{ MARKOR } & \multicolumn{2}{c|}{ MKTOR } \\
\cline { 2 - 5 } & p-value & $\begin{array}{c}\text { Spearman's } \\
\text { rho }\end{array}$ & p-value & $\begin{array}{c}\text { Spearman's } \\
\text { rho }\end{array}$ \\
\hline Market Share & 0.000 & 0.359 & 0.000 & 0.341 \\
\hline Profit & 0.000 & 0.282 & 0.001 & 0.233 \\
\hline Sales & 0.000 & 0.313 & 0.000 & 0.290 \\
\hline Sales Generated by New Products & 0.000 & 0.386 & 0.000 & 0.348 \\
\hline Return on Sales (ROS) & 0.000 & 0.291 & 0.000 & 0.286 \\
\hline Return on Assets (ROA) & 0.000 & 0.386 & 0.000 & 0.380 \\
\hline Return on Investment (ROI) & 0.000 & 0.285 & 0.000 & 0.296 \\
\hline Return on Equity (ROE) & 0.000 & 0.293 & 0.000 & 0.349 \\
\hline Return on Marketing Investment (ROMI) & 0.017 & 0.197 & 0.005 & 0.231 \\
\hline Net Present Value (NPV) & 0.000 & 0.421 & 0.000 & 0.407 \\
\hline Economic Value Added (EVA) & 0.000 & 0.399 & 0.000 & 0.344 \\
\hline Cash Flow Return on Investment (CFROI) & 0.000 & 0.282 & 0.025 & 0.177 \\
\hline Market Value Added (MVA) & 0.000 & 0.340 & 0.013 & 0.208 \\
\hline Balanced Scorecard & 0.000 & 0.391 & 0.000 & 0.329 \\
\hline
\end{tabular}

The intensity of dependence expressed through the Spearman's rho is slightly lower in case of financial indicators than in linkage to non-financial indicators. According to the values of Spearman's rho we can conclude that market orientation has higher impact on non-financial than on financial indicators. Thus, we confirmed our hypothesis.

Gauzente (1999) compared MARKOR and MKTOR method and found out that MARKOR expects the organizational view on market orientation and develop the assessment of business' opportunities. Contrary, MKTOR is more oriented on customer and represents some kind of 
check list (In: Rojas-Méndez, Rod, 2012). Narver and Slater (1990), as the authors of MKTOR, claim that this method is stronger associated with business performance than MARKOR, because is fully represented by serving the added value to customer and increasing the business performance. In our research this corresponds to all non-financial indicators and selected financial indicators: return on assets (ROA), return on investment (ROI), return on equity (ROE) and return on marketing investment (ROMI). On the other side, findings of other researches support the premise that dependence between market orientation and business performance tend to be stronger when the MARKOR method is used for market orientation measurement (In: Vieira, 2010). This is in accordance with our research results in case of prevailing number of financial indicators, namely: overall performance, market share, profit, sales, sales generated by new products, return on sales (ROS), net present value (NPV), economic value added (EVA), cash flow return on investment (CFROI), market value added (MVA) and balanced scorecard (although BSC is specific as it combines both financial and non-financial dimension).

Many scholars (Deshpandé and Farley, 1998; Dobni and Luffman, 2000; Langerak, 2001) also used modified methods or their combination in their studies. Both methods argue that the degree to which a business demonstrates its market orientation influences effectiveness with which the marketing concept is implemented in a business and at the same time the degree by which business performance is affected (Kohli and Jaworski, 1990; Narver and Slater, 1990, Reukert, 1992). Mavondo and Farrell (2000) note that both cultural and behavioral perspectives share the idea that customer is a cornerstone of market orientation and agree that stakeholders try to shape consumer needs and expectations. Rojas-Méndez and Rod (2012) state that both conceptualizations correspond in notion, that the degree to which a business indicates the market orientation influences the effectiveness of marketing concept implementation and the degree to which business performance is affected.

\section{CONCLUSIONS}

In business practice, we can very often observe an imbalance between the perception of the relationship between market orientation and business performance. Financial managers perceive the marketing outcomes from the different point of view in comparison to marketing managers. The main problem with the investments to marketing activities is that it is difficult to quantify the immediate financial outcomes resulting from their implementation. Most of the financial managers do not consider the fulfillment of marketing objectives as sufficient and they require its reflection in financial outcomes. More intensive usage of the marketing performance indicators was caused by the requirements of managers who want to declare the effect of financial sources invested in marketing. Especially, managers try to identify which marketing costs contribute to the financial performance of business. There are always two different points of view. However, we could ask the question if the business with unsatisfied customers can achieve high profit from the long-term point of view. We think that ignoring the marketing indicators with non-financial character and use only traditional financial indicators would be incorrect. From the long-term point of view it is necessary to assess the business objectives as a whole. Simply said, assessing the business performance through the financial indicators is important, but it is not enough. We think that managers should use those methods which include financial and also non-financial indicators. For example, the tool Balanced Scorecard contains four different perspectives which cover both financial and non-financial outcomes. Moreover, thanks to our research results also more financially oriented managers can see that it is worth to pay attention to activities that enhance market orientation as this effort is reflected in improved, not only financial but also non-financial area. 


\section{REFERENCES}

[1] AVLONITIS, G. J., GOUNARIS, S. P. 1997. Marketing orientation and company performance: industrial vs. consumer goods companies. In Industrial Marketing Management, vol. 26, no. 5, p. 385-402

[2] CADOGAN, J. W., DiAMANTOPOUlOS, A. 1995. Narver and Slater, Kohli and Jaworski and the market orientation construct: integration and internationalization. In Journal of Strategic Marketing, vol. 30, no. 4, p. 41-60

[3] CERVERA, A., MOLLÁ, A., SANCHÉZ, M. 2001. Antecedents and consequences of market orientation in public organization. In European Journal of Marketing, vol. 35, no.11/12, p. 1259-1288

[4] DESHPANDÉ, R., FARLEY, J. U. 1998. Measuring Market Orientation: Generalization and Synthesis. In Journal of Market Focused Management, vol. 2, no. 3, p. 213-232

[5] DOBNI, C. B., LUFFMAN, G. 2000. Market Orientation and Market Strategy Profiling: An Empirical Test of Environment - Behavior - Action Coalignment and its Performance Implications. In Management Decision, vol. 38, no. 8, p. 503-519

[6] DUBOVICKÁ, L., VARCHOLOVÁ, T. 2011. Finančné a nefinančné miery strategickej výkonnosti. In Finančný manažér, vol. 11, no. 2, p. 57-60

[7] HOOLEY, G., FAHY, J., GREENLAY, G., BERACS, J., FONFARA, K., SNOJ, B. 2003. Market Orientation in the Service Sector of the Transition Economies of the Central Europe. In European Journal of Marketing, vol. 37, no. 1/2, p. 86-106

[8] KABÁT, L., SOBEKOVÁ MAJKOVÁ, M., VINCÚROVÁ, Z. 2013. Hodnotenie podniku a analýza jeho finančného zdravia. Bratislava : Iura Edition, $160 \mathrm{~s}$.

[9] KOHLI, A. K., JAWORSKI, B. J. 1990. Market Orientation?: The Construct, Research Propositions, and Managerial Implications. In Journal of Marketing, vol. 54, no. 2, p. 90113

[10] KOHLI, A. K., JAWORSKI, B. J. KUMAR, A. 1993. MARKOR : A measure of market orientation. In Journal of Marketing Research, vol. 30, no. 4, p. 467-477

[11] LANGERAK, F. 2001. Effects of Market Orientation on the Behaviors of Salespersons and Purchasers, Channel Relationships, and Performance of Manufacturers. In International Journal of Research in Marketing, vol. 18, no. 3, p. 221-234

[12] LESÁKOVÁ, L. 2004. Metódy hodnotenia výkonnosi malých a stredných podnikov. 1. vyd. Banská Bystrica : Univerzita Mateja Bela, Ekonomická fakulta, $121 \mathrm{~s}$.

[13] MARINIČ, P., 2008. Plánování a tvorba hodnoty firmy. Praha : Grada Publishing, 232 p.

[14] MATSUNO, K, MENTZER, J. T., OZSOMER, A. 2002. The Effects of Entrepreneurial Proclivity and Market Orientation on Business Performance. In Journal of Marketing, vol. 66, no. 3, p. $18-32$

[15] MAVONDO, F. T., FARRELL, M. A. 2000. Measuring market orientation: are there differences between business marketers and consumer marketers? In Australian Journal of Management, vol. 25, no. 2, p. 223-244

[16] NARVER, J. C., SLATER, S. F. 1990. The effect of a market orientation on business profitability. In Journal of Marketing, vol. 54, no. 4, p. 20-35

[17] NARVER, J. C., SLATER, S. F. 1998. Research notes and communications. Customerled and market-oriented: Let's not confuse the two. In Strategic Management Journal, vol. 19, no. 10, p. 1001-1006

[18] PITT, L., CARUANA, A., BERTHON, P. R. 1996. Market orientation and business performance: some European evidence. In International Marketing Review, vol. 13, no. 1, p. 5-18 
[19] PULEDRAN, S., SPEED, R., WIDING II, R. E. 2003. Marketing Planning, Market Orientation and Business Performance. In European Journal of Marketing, vol. 37, no. 3/4, p. 476-497

[20] ROJAS-MÉNDEZ, J. I., ROD, M. 2012. Chilean wine producer market orientation: comparing MKTOR versus MARKOR. In International Journal of Wine Business Research, vol. 25 , no. 1, p. 27-49

[21] RUEKERT, R. W. 1992. Developing a Market Orientation: An Organizational Strategy Perspective. In International Journal of Research in Marketing, vol. 9, no. 3, p. 225-245

[22] VIEIRA, V. A. 2010. Antecedents and consequences of market orientation: a Brazilian meta-analysis and an international meta-analysis. In Brazilian Administration Review, vol. 7, no. 1, p. $40-58$ 